No 3981

Studia nad Autorytaryzmem i Totalitaryzmem 42, nr 1

Wrocław 2020

https://doi.org/10.19195/2300-7249.42.1.2

\author{
TOMASZ TULEJSKI \\ ORCID: 0000-0001-9466-1173 \\ Uniwersytet Łódzki \\ ttulejski@o2.pl
}

\title{
Od posłuszeństwa do tyranobójstwa. Ewolucja prawa oporu w teologii politycznej Johna Knoxa
}

\begin{abstract}
Abstrakt: Myśl polityczna reformacji i kontrreformacji po rozpadzie Christianitas po raz kolejny postawiła pytania o zakres posłuszeństwa i możliwość czynnego oporu wobec tyranii. Spośród ojców doktryny uzasadniającej sprzeciw wobec władzy należy wskazać przede wszystkim Johna Knoxa, uważanego za jednego z założycieli szkockiej reformacji. Ten prominentny kaznodzieja i teolog jest także, obok George'a Buchanana i Samuela Rutherforda, jednym z klasyków anglosaskiej koncepcji prawa oporu.

W artykule autor dowodzi, że Knox, wychodząc od stanowiska nakazującego obowiązek posłuchu wobec monarchy i dopuszczającego jedynie bierny opór, ostatecznie odchodzi od umiarkowanego stanowiska Jana Kalwina i Heinricha Bullingera. Jego argumentacja, pod wpływem wydarzeń politycznych w Szkocji i Anglii oraz radykalnych koncepcji pisarzy kalwińskich, zmierza do uzasadnienia powszechnej rewolucji, a nawet królobójstwa. Ewolucja jego poglądów zdaniem autora spowodowana była zmianami sytuacji politycznej i religijnej w Szkocji i Anglii. Rządy katolickich królowych — Marii de Guise, Marii Tudor i Marii Stuart — spowodowały radykalizację jego politycznych poglądów, których sensem było bezlitosne zwalczanie herezji i bałwochwalstwa oraz obrona prawdziwej wiary. Jego koncepcje miały zdaniem autora wielki wpływ na angielskich purytanów - to między innymi jemu angielski purytanizm zawdzięczał swą radykalizację. To Knox był również w dużym stopniu odpowiedzialny za postawę szkockich prezbiterian podczas rewolucji purytańskiej, a jego myśl była istotną inspiracją najbardziej radykalnych koncepcji tego okresu.

W artykule autor zastosował metodę kontekstowej analizy dzieł i wypowiedzi Knoxa, stosując klucz chronologiczny. Pozwoliło mu to na wykazanie ścisłej korelacji między poglądami Knoxa na prawo oporu a zapotrzebowaniem bieżącej debaty politycznej. Autor dochodzi ostatecznie do wniosku, że to właśnie okoliczności polityczne, a nie poglądy teologiczne uczyniły z Knoxa monarchomachę.
\end{abstract}

Słowa kluczowe: Knox, prawo oporu, tyranobójstwo. 


\title{
FROM OBEDIENCE TO TYRANNICIDE: \\ EVOLUTION OF THE RIGHT OF RESISTANCE IN JOHN KNOX'S POLITICAL THEOLOGY
}

\begin{abstract}
The political thought of the Reformation and Counter-Reformation after the collapse of Christianitas once again raised questions about the extent of obedience and the possibility of active resistance to tyranny. One of the fathers of the doctrine which justified resistance to power was John Knox, considered also as one of the fathers of the Scottish Reformation. This prominent preacher and theologian was also, along with George Buchanan and Samuel Rutherford, one of the classics of the Anglo-Saxon concept of the right to resist and the right of rebellion.

In the article, the author argues that Knox, starting from the position requiring obedience to the monarch and allowing only passive resistance, ultimately deviated from the moderate position of John Calvin and Heinrich Bullinger. His argument, influenced by political events in Scotland and England, and the radical concepts of Calvinist writers, tended to justify general revolution and even regicide. According to the author, the evolution of his views was caused by changes in the political and religious situation in Scotland and England. The rule of Catholic queens - Maria de Guise, Mary Tudor, and Mary Stuart — radicalised his political views, whose sense was to mercilessly fight heresy and idolatry and defend true faith. His ideas, according to the author, had a great impact on English puritans - thanks to him English puritanism obtained its radicalisation. Knox was also largely responsible for the attitude of Scottish Presbyterians during the Puritan Revolution, and his thought became largely the inspiration for the most radical concepts of this period.

In the article, the author adopts the method of contextual analysis of Knox's works and statements using a chronological key. This allows him to demonstrate a close correlation between Knox's views on the law of resistance and the demand for ongoing political debate. The author finally concludes that political circumstances, not theological views, made Knox a monarchomach.
\end{abstract}

Keywords: Knox, right of resistance, tyrannicide.

Rebelia przeciw tyranom jest obowiązkiem wobec Boga.

John Bradshaw

Rozpad chrześcijańskiej jedności Europy w wyniku rewolucji protestanckiej, definitywnie kończący istnienie uniwersalnej Republica Christiana, także w dziejach zachodniej refleksji polityczno-prawnej zamyka pewien etap jej rozwoju, równocześnie otwierając nowy, z którego wyrastają korzenie współczesności oraz porządkujących ją pojęć politycznych. Mimo że myśl polityczna reformacji i kontrreformacji tkwi jeszcze głęboko w średniowiecznej siatce pojęć, stara się na nowo zdefiniować zasady fundamentalne oraz udzielić odpowiedzi na pytania postawione w zupełnie nowej religijno-politycznej rzeczywistości. Jej cechą charakterystyczną jest bowiem pojawienie się religijnego pluralizmu, który stawia przed chrześcijanami problem, a po raz ostatni na taką skalę pojawił się w czasach pogańskiego jeszcze Rzymu — jaki stosunek winien mieć chrześcijanin do państwa niepodzielającego jego religijnych zapatrywań?

Studia nad Autorytaryzmem i Totalitaryzmem 42, nr 1, 2020

C) for this edition by CNS 
Zanim Imperium Romanum oddało pokłon Bogu, odpowiedzi na to pytanie udzielił biskup Hippony w traktacie konstytuującym tożsamość Europy i określającym chrześcijańską perspektywę na kolejne tysiąc lat. W De civitate Dei pisze on bowiem o tyrańskich władcach, przytaczając przykład Nerona:

Ale i tacy znikąd, jeno od Opatrzności Boskiej władzę panowania mają, gdy Bóg osądzi, że ludzie na takich władców zasługują. Wyraźnie o tym zapewnia nas mądrość Boża w tych Boskich słowach: „Przeze mnie królowie królują, a tyrani przeze mnie dzierżą ziemię”. Żeby zaś kto nie myślał, że tyrani nie oznaczają tu złych i niegodziwych królów, lecz w znaczeniu dawnym tego słowa wszelkich potężnych władców [...] żeby więc kto tak nie sądził, jest wyraźnie w innym miejscu Pisma tak powiedziane o Bogu: „Iż sprawia on, iżby królował człowiek obłudnik dla przewrotności ludu"1.

Obowiązkiem chrześcijanina jest więc posłuszeństwo i bezwzględny zakaz buntu, albowiem każda władza pochodzi od Boga. Tym, co dopuszcza biskup Hippony, jest bierne posłuszeństwo, gdy nakazy władzy są sprzeczne z prawem bożym.

Inaczej na to samo pytanie odpowiadają jednak w XVI wieku protestanci i katolicy, którym przyszło żyć w nieprzyjaznym wyznaniowo państwie. Nie bez przyczyny zatem okres ten obfituje w całkowicie nowe ujęcia problemu posłuszeństwa wobec władzy, formułowane po obu stronach wielkiego teologiczno-politycznego sporu. Szczególne zasługi na tym polu ma z całą pewnością tradycja kalwińska, paradoksalnie najsilniej osadzona w tradycji augustiańskiej, z której wywodzą się najbardziej radykalne stanowiska uzasadniające prawo oporu, a nawet tyranobójstwo. Choć sam Kalwin zachowywał w tej kwestii uzasadnioną powściągliwość (mimo że jego stanowisko z czasem ewoluowało), wielu jego uczniów nie cechował właściwy mu sceptycyzm wobec rewolucji, dlatego wychodząc poza nauczanie swego mistrza, dostosowywali swe stanowisko do okoliczności i potrzeb politycznych².

Klasycznym przykładem są tutaj francuscy hugenoci (Theodore Beza, François Hotman, Philippe du Plessis-Mornay) i szkoccy prezbiterianie, którzy w konflikcie z katolickimi władcami nie cofali się przed teologicznym uzasadnieniem potrzeby czynnego oporu. Jednym z nich był uczeń Kalwina, uważany za ojca szkockiej reformacji — John Knox. Jego poglądy dotyczące stosunku wobec bałwochwalczych władców podlegały w ciągu jego życia istotnej ewolucji. Dlatego celem niniejszego artykułu jest wykazanie, że była ona nie tyle wynikiem zasadniczych zmian w jego poglądach teologicznych, ile efektem zmieniającej się rzeczywistości politycznej szesnastowiecznej Szkocji i Anglii. Z tego też względu na początku krótko zarysuję stanowisko Kalwina jako punkt odniesienia dalszych rozważań. Wskażę w tym miejscu także pewne niekonsekwencje jego stanowiska, otwierające drogę radykalnym interpretacjom jego następców. Następnie

1 Augustyn z Hippony, Państwo Boże, przeł. W. Kubicki, Kęty 2002, V, XIX, s. 211.

2 T. Szczech, Państwo i prawo $w$ doktrynie św. Augustyna, Marcina Lutra i Jana Kalwina, Łódź 2006, s. 295.

Studia nad Autorytaryzmem i Totalitaryzmem 42, nr 1, 2020

(C) for this edition by CNS 
przedstawię pierwotne stanowisko Knoxa, zbieżne z początkowymi poglądami jego mistrza. W końcu zarysuję religijny kontekst panowania Marii de Guise oraz Marii Tudor, których działania stały się powodem intelektualnej wolty Knoxa i zajęcia przez niego stanowiska bliskiego poglądom francuskich monarchomachów oraz uzasadniającego powszechną rebelię.

\section{Poglądy Kalwina na prawo oporu - ewolucja doktryny}

Zgodnie z teocentrycznym stanowiskiem Kalwina rząd jest ustanowionym przez Boga porządkiem, będącym konsekwencją ludzkiego grzechu, i równocześnie pewnym ograniczonym remedium na deprawację natury człowieka. Bez niego wszelkie relacje społeczne byłyby niemożliwe, albowiem rząd „pomaga w konsolidacji ludzkich społeczeństw” oraz „opiera się furii niegodziwych i chroni niewinnych przed ich przemocą" ${ }^{3}$, nawet jeśli jest dalece niedoskonały. Mimo to jest potrzebny ludzkości nie mniej niż chleb, woda, słońce i powietrze, a jako manifestacja bożej opatrzności zasługuje na posłuszeństwo i szacunek. Opieranie się mu byłoby więc nie tylko „określeniem siebie jako wroga rodzaju ludzkiego”, lecz także „wzgardzeniem opatrzności tego, który jest założycielem władzy politycznej"4. Dlatego pierwotnie poglądy Kalwina w kwestii postawy wobec tyrańskiej władzy były zgodne z przemyśleniami św. Augustyna. Odmawiał więc legitymacji jakiejkolwiek próbie czynnego sprzeciwu, stojąc konsekwentnie na stanowisku, że wszelka władza pochodzi od Boga — zarówno w wymiarze abstrakcyjnym, jak i personalno-konkretnym. Rząd nie jest bowiem dziełem człowieka, lecz został powołany do życia przez samego Stwórcę.

Pan nie tylko zapewnia — dowodzi więc — że urząd urzędnika jest uznany i zaakceptowany przez niego, lecz że od niego pochodzi jego godność wraz z najbardziej zaszczytnymi tytułami i to on wspaniałomyślnie go nam daje. Wystarczy wspomnieć, że ci, którzy służą jako urzędnicy, nazywani są „,bogami” i niech nikt nie myśli, że nie ma to wielkiej wagi. Ponieważ ma to znaczenie, gdyż mają upoważnienie od Boga i są obdarzeni boską władzą, będąc całkowicie reprezentantami Boga działającymi jako jego zastępcy ${ }^{5}$.

Posłuszeństwo wobec władzy wynika zatem z samego Pisma Świętego. Wobec tego bożą legitymację ma zarówno sprawiedliwy i pobożny władca, jak okrutny i bezbożny tyran. Nawet w ostatnim wydaniu Institutio religionis christianae z 1559 roku Kalwin pisał:

3 J. Calvin, Commentaries on the Epistle of Paul the Apostle to the Romans, XIII, 3, Edinburgh 1849 , s. 480.

4 Ibidem, XIII, 1, s. 478.

5 J. Calvin, Institutes of the Christian Religion, IV, XX, 4, t. 2, Louisville 1960, s. 1489; jeśli nie podano inaczej, przeł. T.T.

Studia nad Autorytaryzmem i Totalitaryzmem 42, nr 1, 2020

(C) for this edition by CNS 
Dlatego, choć jesteśmy okrutnie dręczeni przez bezlitosnego księcia, zachłannie grabieni przez tego, który jest chciwy lub swawolny, zaniedbywani przez tego, który jest gnuśny, jeśli w koncu jesteśmy dręczeni za swą pobożność przez tego, który jest świętokradczy i bluźnierczy, powinniśmy najpierw sami być świadomi swych własnych występków, które bez wątpienia są ukarane w ten sposób przez bicz zesłany przez Pana ${ }^{6}$.

Kalwin dopuszcza jedynie poddanie się władzy tyrana i gorliwą modlitwę do Boga ${ }^{7}$. Jeśli więc ktoś wszczyna rebelię przeciwko władzy, działa przeciwko boskiemu porządkowi oraz jest odpowiedzialny za anarchię i upadek wspólnoty. Jedyny wyjątek, jaki przewiduje, to klasyczna w myśli chrześcijańskiej rozbieżność między wolą władcy a nakazami Boga. W tej sytuacji chrześcijanin może jedynie odmówić posłuszeństwa i cierpieć za niewykonanie nakazu prawa. Posłuszeństwo chrześcijanina wobec władzy bowiem ,nigdy nie odciągnie nas od posłuszeństwa temu, którego woli pragnienia wszystkich królów powinny być podporządkowane" 8 .

Choć Kalwin odrzuca konsekwentnie indywidualne prawo oporu, to klasyczne augustiańskie stanowisko ulega jednak u niego osłabieniu. Dzieje się tak za sprawą sformułowanej pod koniec życia tak zwanej teorii eforalnej ${ }^{9}$. W wydaniu Institutio z 1559 roku pytanie, które w 1536 roku roku brzmiało ,jak wiele szacunku osoba prywatna winna swym urzędnikom i jakie posłuszeństwo jest im winna?", zmienia się teraz bowiem w ,jak wiele szacunku osoba prywatna winna swym urzędnikom i jak długo posłuszeństwo jej powinno trwać?” oraz ,jak daleko jej posłuszeństwo powinno sięgać?"10. Tym samym Kalwin dał jasno do zrozumienia, że jego wcześniejsze poglądy na prawo oporu zostały zasadniczo przewartościowane $^{11}$. Choć nie zdecydował się co prawda na przyznanie prawa czynnego oporu poddanym, uczynił jednak istotny wyłom w swej argumentacji ${ }^{12}$. Był bowiem przekonany, że w każdym ustroju niebędącym monarchią absolutną w wymiarze faktycznym istnieją zawsze królewscy ministrowie, książęta krwi czy parlamenty, w nich upatrując środka obrony przed tyranią. Podstawą takiego

6 Ibidem, IV, 20, 29, t. 2, s. 1516.

7 W. Nijenhuis, Ecclesia Reformata. Studies on the Reformation, t. 2, Leiden-New York-Köln 1994, s. 74.

8 J. Calvin, Institutes..., IV, XX, 29, t. 2, s. 1517.

9 Świadomie nie poruszam tutaj dwóch pozostałych wyjątków od nakazu posłuszeństwa władzy - tak zwanego casusu wybawiciela oraz teorii ekscesu — jako nieprzydatnych do dalszych rozważań.

10 W. Nijenhuis, op. cit., s. 75.

$11 \mathrm{Z}$ tego okresu pochodzą też radykalne w swej wymowie słowa z Komentarzów do Księgi Daniela, w których Kalwin pisze, że „ziemscy władcy porzucają swą władzę, kiedy podnoszą rękę przeciwko Bogu i stają się niegodni, by zaliczyć ich między ludzi. Powinniśmy raczej — kontynuuje — całkowicie ich odrzucić, niż kiedykolwiek dawać im posłuch kiedy są narowiści i chcą pozbawić Boga jego praw i uczepić się jego tronu, by ściągnąć go z nieba na dół" - idem, Commentaries on the Book of the Daniel, t. 1, Edinburgh 1852, s. 382.

12 B. Szlachta, Konstytucjonalizm czy absolutyzm? Szkice z francuskiej myśli politycznej XVI wieku, Kraków 2005, s. 353-354.

Studia nad Autorytaryzmem i Totalitaryzmem 42, nr 1, 2020

(C) for this edition by CNS 
poglądu jest przekonanie, że nie tylko władza królewska pochodzi pod Boga, lecz przymiot ten przysługuje każdej władzy, także tej, którą dzierżą pozostali urzędnicy publiczni.

Jeżeli ustanowieni zostali urzędnicy ludu — pisze Kalwin — by powstrzymywać samowolnych królów (jak w starożytnych czasach eforowie zostali ustanowieni przeciwko królom Sparty, trybuni ludowi przeciwko rzymskim konsulom, demarchowie przeciwko senatowi Aten i być może czymś podobnym jest w każdym królestwie władza przyznana zgromadzeniu trzech stanów), to jestem daleki, by zabraniać im, by opierali się, zgodnie ze swym obowiązkiem, dzikiej rozpuście królów tak, że jeżeli nie zwracaliby uwagi na królów, którzy gwałtem napadaliby i atakowali zwykły lud, wtedy oświadczam, że ich bezczynność jest niegodziwą perfidią, ponieważ ich bezczynność jest zdradą wolności ludu, której obrońcą zostali wyznaczeni przez Boga ${ }^{13}$.

Pisząc o podmiotach uprawnionych do przeciwstawienia się tyranowi, Kalwin nie ma więc prawdopodobnie na myśli niższych urzędników królewskich, lecz populares magistratus, którzy zostali wyznaczeni przez lud, aby opierać się tyranicznym władcom ${ }^{14}$, lub tych, którzy jedynie na mocy zwyczaju i prawa są reprezentantami królestwa. Prawo wypowiedzenia posłuszeństwa tyrańskiemu władcy Kalwin w praktyce przyznaje tym samym zgromadzeniom stanowym (choć za jego życia parlament Francji nie zebrał się ani razu ${ }^{15}$ ) lub — jak pisze gdzie indziej książętom krwi występującym wspólnie przeciwko władcy naruszającemu wolności poddanych ${ }^{16}$. Pamiętać więc trzeba, że Kalwin z niechęcią patrzył na wszelkie formy ludowej niesubordynacji czy rewolucji ${ }^{17}$, dlatego w 1557 roku w liście do paryskiego zboru pisał, że „lepiej byłoby, gdybyśmy wszyscy popadli w ruinę, niżby ewangelia Boga została wystawiona na hańbę ludzi uzbrojonych do przewrotu i zamieszek"18. To natomiast, co Kalwin dopuszczał w ramach teorii eforalnej, to na przykład sprzeciw książąt broniących prawdziwej wiary przeciwko papistowskiemu cesarzowi czy najwyższych urzędników Królestwa Francji przeciwko królowi, który sięga po tyrańskie praktyki. Dlatego w liście do admirała Coligny pisał chociażby, że ,gdyby książęta krwi byliby przekonani o swym uprawnieniu dla dobra wspólnego i jeśli Parament dołączyłby do nich w ich sporze, to byłoby legalne dla wszystkich dobrych poddanych udzielenie im pomocy w zbrojnym

13 J. Calvin, Institutes..., IV, XX, 29, t. 2, s. 1519.

14 Q. Skinner, The Foundations of Modern Political Thought, t. 2. The Age of Reformation, New York 1978, s. 232-233.

15 J.T. McNeill, The History and Character of Calvinism, New York 1954, s. 224.

16 T. Szczech, op. cit., s. 293. Przejawem radykalizacji poglądów Kalwina jest też zmiana jego zapatrywań na kwestie ustrojowe. Początkowo uznawał trzy czyste formy uprawnione po równo i jednocześnie tak samo zagrożone tyranią, preferując jednak arystokrację. Po 1543 roku tymczasem zdecydowanie preferuje on ustój będący mieszaniną arystokracji i demokracji jako lepiej gwarantujący wolność ludu niż czysta arystokracja i monarchia; zob. W. Nijenhuis, op. cit., s. 75; H. Höpfl, The Christian Polity of John Calvin, New York-New Rochelle-Melbourne 1982, s. 161.

17 J.T. McNeill, Calvin and civil government, [w:] Readings in Calvin's Theology, red. D. McKim, Grand Rapids 1984, s. 268.

18 J. Calvin, To the church of Paris, [w:] Letters of John Calvin, t. 3, Philadelphia 1858, s. 361.

Studia nad Autorytaryzmem i Totalitaryzmem 42, nr 1, 2020

C) for this edition by CNS 
oporze"19. Co istotne jednak, Kalwin nigdy nie przyznał prawa indywidualnego oporu, a działanie takie mogła podjąć tylko cała wspólnota polityczna na wezwanie i pod przywództwem „niższych urzędników”; nigdy też nie pochwalał prywatnego prawa oporu ${ }^{20}$.

\section{Początkowe poglądy Knoxa - od biernego oporu do potępienia tyranii}

Na początku analizy koncepcji politycznych Knoxa należy dokonać przede wszystkim zastrzeżenia, że nie był on usystematyzowanym i samodzielnym myślicielem politycznym, lecz teologiem, kaznodzieją i głosicielem Ewangelii, stylizującym się na proroka Jeremiasza. Niełatwo więc z jego pism wydobyć warstwę normatywną - mają one najczęściej formę listów, kazań i napomnień. Dlatego w kwestiach nas interesujących Knox odwoływał się przede wszystkim do nauczania Kalwina i jego teologii władzy zarysowanej w Institutio. Dla niego również państwo jest darem boskiej opatrzności, danym zdeprawowanym ludziom, żeby mogli egzystować w społeczeństwie, darem, który choć częściowo potrafi okiełznać ich upadłą naturę. $Z$ tego względu początkowe poglądy Knoxa na problem oporu niczym w istocie nie różnią się od tych, które prezentował Kalwin w pierwszych wydaniach Institutio. Zgodnie bowiem z tradycją augustiańską nie miał wątpliwości, że na poddanych spoczywa wywiedziony z Pisma Świętego obowiązek posłuszeństwa wobec władzy, który kończy się tam, gdy jest ono sprzeczne $\mathrm{z}$ prawem bożym ${ }^{21}$. W liście do kongregacji w Barwick (co ważne, jako nadworny kaznodzieja królewski, na miesiąc przed śmiercią Edwarda VI) w 1552 roku przekonywał:

Pamiętajmy zawsze, ukochani bracia, że winniśmy należne posłuszeństwo urzędnikom, władcom i książętom, bez wzniecania niepokojów, urazy i buntu. Jakkolwiek niegodziwi są oni w swym życiu, jakkolwiek bezbożne są ich nakazy [...], nie rościcie sobie prawa, by bronić bożej prawdy lub religii (jako poddani) za pomocą przemocy lub miecza, lecz cierpliwie cierpcie, co będzie oznaką stałości waszej wiary i religii 22 .

Choć Knox nie popierał całkowicie kierunku dokonywanych w Anglii zmian religijnych, bez wątpienia za panowania Edwarda VI Anglia stała się w jego opinii krajem protestanckim. Sytuacja diametralnie się zmieniła wraz z akcesją katolickiej Marii Tudor, która przez próbę restytucji katolicyzmu w jego opinii zerwała

19 J. Calvin, To the admiral Coligny, [w:] Letters of John Calvin, t. 4, s. 176.

20 C. Camion, The right of resistance in Jean Calvin and the Monarchomachs, „La revue de philosophie de l'Université de Montréal" 2009, nr 5, s. 7.

21 R.L. Greaves, John Knox, the reformed tradition, and the development of resistance theory, „The Journal of Modern History” 48, 1976, nr 3. On Demand Supplement, s. 2.

22 J. Knox, Epistle to the congregation of Berwick, [w:] John Knox and the Church of England, London 1875, s. 259.

Studia nad Autorytaryzmem i Totalitaryzmem 42, nr 1, 2020

(C) for this edition by CNS 
przymierze z Bogiem. Zmieniły się równocześnie poglądy Knoxa, który musiał odnaleźć się w nowych, niesprzyjających okolicznościach ${ }^{23}$. Tuż po wstąpieniu na tron nowej królowej w A godly letter of warning or admonition to the faithful in London, Newcastle, and Berwick z 1553 roku wskazywał, powołując się na Deuteronomium, na konsekwencję rządów bałwochwalcy i obowiązkach, jakie z tego tytułu spoczywają na ludzie bożym:

Bałwochwalstwo powoduje gniew i rozpala oburzenie Boga, które nie jest zaspokojone, dopóki winowajcy i wszystko, co posiadają, nie zostanie usunięte z powierzchni ziemi, ponieważ nakazał ich ukamienowanie i spalenie ich posiadłości, a jeśli miasto winne było wykroczenia, miało być zniszczone bez litości. Może się to wydawać wyrokiem surowym, lecz jeśli wziąć pod uwagę przyczynę [...], to sam Bóg oświadcza, że jego wrogowie są naszymi wrogami. Dlatego wszyscy ci, którzy odciągają nas od Boga (będąc królami lub królowymi), są wcieleniem diabła, są wrogami Boga, a na mocy bożej woli oświadczamy, że w takim wypadku są także naszymi wrogami, ponieważ powinniśmy zrozumieć, jak wstrętne jest bałwochwalstwo w jego obecności i nie możemy utrzymać przymierza między nim a nami, jeśli wybieramy, wyznajemy lub znosimy bałwochwalstwo ${ }^{24}$.

Nie kryje też swej antypatii do Marii Tudor, z odrazą nazywając ją zdradzieckim, kłamliwym, oszukańczym monarchą i zdrajcą angielskiej korony. Nie nawołuje jednak do rebelii, lecz do modlitwy, by Bóg zesłał nowego Fineasza, Eliasza czy Jehu ${ }^{25}$. Nie oznaczało to przy tym, że Knox zmienił nagle poglądy i podejście do prawa oporu, choć być może wtedy narodziły się u niego pewne pomysły, które musiał jeszcze dopracować i skonsultować. Okazja ku temu nadarzyła się niebawem, gdy przezornie uszedł z Anglii w styczniu 1554 roku po objęciu tronu przez Marię. Być może w ten sposób uniknął losu Cranmera, Rogersa, Hoopera, Latimera i wielu innych, którzy spłonęli na stosie. W międzyczasie również sytuacja w Szkocji się zmieniła, albowiem po śmierci Jakuba V regencję, w imieniu małoletniej Marii Stuart, objęła jego żona - Maria de Guise - nieciesząca się popularnością wśród kalwinistów, obawiających się powrotu katolicyzmu.

Dlatego też Knox w czasie emigracji, w trakcie swojego pobytu w Genewie i Zurychu, zadał Kalwinowi i Bullingerowi (i być może również Viretowi) pytania dotyczące zakresu posłuszeństwa oraz możliwego uzasadnienia oporu ${ }^{26}$. Niestety odpowiedzi Kalwina nie znamy, ponieważ miały charakter ustny, a Bullinger, zdający mu relację ze spotkania, daleki był od poparcia rewolucji ${ }^{27}$. Zapewne pod ich wpływem Knox w 1554 roku skierował z Genewy list do angielskich kalwinów,

23 R.M. Reeves, English Evangelicals and Tudor Obedience, c. 1527-1570, Leiden-Boston 2014, s. 138.

24 J. Knox, A godly letter of warning or admonition to the faithful in London, Newcastle, and Berwick 1553, [w:] The Works of John Knox, t. 3, Edinburgh 1895, s. 193.

25 Prezentuje zatem podejście bardzo podobne do „casusu wybawiciela” Kalwina; zob. T. Szczech, op. cit., s. 290-291.

26 G. MacGregor, The Thundering Scot, Philadelphia 1957, s. 68.

27 W.S. Reid, John Knox's theology of political government, „Sixteenth Century Journal” 19, 1988, nr 4, s. 553; R.M. Reeves, op. cit., s. 139.

Studia nad Autorytaryzmem i Totalitaryzmem 42, nr 1, 2020

(C) for this edition by CNS 
w którym nakłaniał do posłuszeństwa wobec katolickiej królowej, mimo że uważał ją za gorszą od Jezebel ${ }^{28}$, „która nigdy nie wzniosła w całym Izraelu połowy szubienic, ile złośliwa Maria w samym tylko Londynie"29. W jego zakończeniu czytamy:

Dlatego, ukochani w Panu, oczekujcie cierpliwie wyswobodzenia przez Pana, stroniąc od takich wykroczeń, które mogą oddzielić was od błogosławionej wspólnoty w Panu Jezusie w czas jego powtórnego przyjścia. Czuwajcie i módlcie się, opierajcie się diabłu, wiosłujcie przeciw gwałtownej burzy, a niebawem Pan obdarzy wasze serca spokojem, które teraz są dręczone cierpieniem i niepokojem ${ }^{30}$.

Porównanie Marii do Jezebel nie wydaje się przypadkowe. Gdy odwołamy się bowiem do treści 2 Księgi Królewskiej (9, 30-37), opisującej jej śmierć, wtedy jasne stanie się, że Knox nie miałby zapewne nic przeciwko krwawej rewolcie wymierzonej przeciwko ,przeklętej bałwochwalczyni, winnej krwi proroków Pańskich"31. Nie zdecydował się jednak na wyrażenie expressis verbis swych poglądów, lecz używając biblijnych odniesień i aluzji, pozostawił czytelnikom wyprowadzenie z nich wniosków, nie sprzeciwiając się równocześnie wprost kalwińskiej ortodoksji. Jego atak na Marię Tudor, a przy okazji Karola V, którego nazwał „cesarzem, który jest nie mniejszym wrogiem Chrystusa niż kiedyś Neron"32, spowodował jednak, że został zmuszony przez władze miejskie do opuszczenia Frankfurtu, będącego schronieniem dla angielskich uciekinierów ${ }^{33}$. W 1556 roku został w Szkocji ekskomunikowany przez władze kościelne i jako heretykowi groziła mu śmierć na stosie (na szczęście udało się jedynie publicznie spalić jego portret). Fakt ten musiał wpłynąć na jego postawę wobec Marii de Guise, której stał się zaciekłym krytykiem.

Dlatego pięć lat później Knox swe rewolucyjne poglądy wyraził już o wiele jaśniej w A brief exhortation to England, choć nie znajdujemy w nim żadnej nowej konstrukcji mającej uzasadnić czynny opór. Jest to raczej, jak często u niego, wzorowane na starotestamentowych prorokach upomnienie i przestroga. Odwołując się zatem do przykładów ze Starego Testamentu, otwarcie wzywał do obalenia Marii, wskazując, że jest obowiązkiem Anglii, by przestała, zanim będzie za późno (nie wskazując jednak wprost formy takiej rebelii), „karmić na swym łonie pokolenie żmijowe”; w przeciwnym razie ściągnie na siebie bożą zemstę. ,[Z]byt późny będzie — przekonywał — twój lament i płacz, gdy spali cię płomień bożego gniewu"34.

28 A. Lang, Knox and the Reformation, Whitefish 2004, s. 50-51; G.P. Fisher, The Reformation, New York 1873, s. 360.

29 J. Knox, A faithful admonition to the professors of God's truth in England 1554, [w:] The Works of John Knox, t. 3, s. 294.

30 Ibidem, s. 329-330.

31 Ibidem, s. 294.

32 Ibidem, s. 308.

33 W.S. Reid, Trumpeter of God, New York 1974, s. 127.

34 J. Knox, A brief exhortation to England, for the speedy embracing of the gospel heretofore by the tyranny of Mary suppressed and banished 1559, [w:] The Works of John Knox, t. 5, s. 521.

Studia nad Autorytaryzmem i Totalitaryzmem 42, nr 1, 2020

(C) for this edition by CNS 
Rok wcześniej jednak ukazała się jedna z najsłynniejszych prac Knoxa The first blast of the trumpet against the monstruous regiment of women - będąca bezpośrednim atakiem na Katarzynę Medycejską, Marię de Guise oraz Marię Tudor i kolejnym etapem w rozwoju teoretycznego uzasadnienia buntu przeciwko bałwochwalczym władcom. Choć myśliciel mówi o tym nie wprost, to sam przyznaje, że „może być to odczytane jako zachęta do buntu”35. Warto o niej wspomnieć także z tego powodu, że Elżbieta I, mimo że nie była przedmiotem ataku, uważała, że pamflet ten pośrednio wymierzony jest również w nią, dlatego gdy Knox wracał do Szkocji, zabroniła mu przejazdu przez terytorium Anglii, gdzie odtąd stał się persona non grata. Dowodził bowiem w tekście, jak zawsze posiłkując się Starym Testamentem, a teraz i przykładami historycznymi, że ,jest bardziej niż potworne wobec natury, by kobieta panowała i miała władzę nad mężczyzną" 36 . Kobiety według Knoxa zostały przez Boga pozbawione prawa do dzierżenia korony i władania mężczyznami. Jak przekonywał:

Promowanie kobiety, by sprawowała rządy, zwierzchnictwo, dominium lub imperium nad jakimś królestwem, narodem lub miastem, jest niezgodne z naturą, jest zniewagą wobec Boga, rzeczą najbardziej sprzeczną z Jego objawioną wolą i autoryzowanym nakazem, w końcu jest to obaleniem właściwego porządku, wszelkiej słuszności i sprawiedliwości ${ }^{37}$.

Nawiązując do biblijnych przykładów, Knox nawoływał nawet do obalenia takiej władzy i zabicia królowej, wskazując, że mężczyzn nie wiąże obowiązek posłuszeństwa wobec kobiety. Taki prymitywizm i radykalizm zaniepokoił nawet Kalwina, który komentując The first blast (a w istocie tłumacząc, że nie powstał on z jego inspiracji), w liście do Williama Cecila (co z pewnością nie było przypadkiem, był on bowiem kanclerzem Elżbiety I, która niebawem po publikacji pamfletu objęła tron) wskazywał, że istnieją przykłady kobiet (Chulda i Debora) „wyniesionych przez Boga, by potępić bierność mężczyzn lub w ten sposób pokazać wyraźniej swą własną chwałę". Dlatego, zdając sobie sprawę z oczywistego rewolucyjnego kontekstu wywodów Knoxa i ewentualnych skutków dla angielskich kalwinów, raz jeszcze podkreślił, że

nie jest dozwolone, by podważać rządy, które zostały ustanowione przez szczególną bożą opatrzność, a na mocy zwyczaju, powszechnego przyzwolenia rządy nad królestwami i księstwami mogłyby dziedzicznym prawem być przenoszone na kobiety ${ }^{38}$.

Tłumaczył też wyraźnie, że praca została opublikowana na rok przed tym, zanim w ogóle dowiedział się o jej istnieniu. Pokazuje to, że choć Kalwin cenił wysoko Knoxa, to niektóre jego pomysły wzbudzały w nim sprzeciw, a co najmniej zdziwienie. Mimo to wkrótce Knox opublikował The second blast of

35 J. Knox, The first blast of the trumpet against the monstruous regiment of women, [w:] The Works of John Knox, t. 4, s. 367.

36 Ibidem.

37 Ibidem, s. 373.

38 J. Calvin, To William Cecil, [w:] Letters of John Calvin, t. 4, s. 47.

Studia nad Autorytaryzmem i Totalitaryzmem 42, nr 1, 2020

(C) for this edition by CNS 
the trumpet, w którym rozwija swą argumentację, wskazując już bezpośrednio podstawy do wypowiedzenia władcy posłuszeństwa. Twierdzi więc, że to nie dziedziczenie jest podstawą legitymacji władzy, ale przestrzeganie praw bożych. Dlatego żaden ich naruszyciel i bałwochwalca nie może sprawować urzędu publicznego w państwie lub mieście, które wyznaje prawdziwą religię; żaden węzeł posłuszeństwa nie wiąże też poddanych z tyranem, który występuje przeciwko Bogu i Jego prawdzie. W końcu Knox oświadcza:

Jeśli [ludzie] nierozważnie wypromowali jakąś niegodziwą osobę lub nieświadomie wybrali ją, to po tym, jak okaże się niegodna władzy nad ludem bożym (jak jest z bałwochwalcami i okrutnymi prześladowcami), to sprawiedliwie ci sami ludzie mogą usunąć ją i ukarać ${ }^{39}$.

Tyran przestaje być więc karą za grzechy, jaką Bóg zsyła na występnych $\operatorname{ludzi}^{40}$, a staje się sługą szatana, którego władzę dzieci boże muszą zwalczać.

\section{Covenant — od teorii eforalnej do powszechnej rebelii i tyranobójstwa}

W pismach $\mathrm{z}$ tego okresu daje się więc zauważyć pewien element, który potem stanie się jądrem argumentacji Knoxa na rzecz rebelii. Instrumentem teologicznym, który pozwala wyjść poza nauczanie Kalwina w kwestii prawa oporu i odwołanie się do zaczerpniętych ze Starego Testamentu wzorców jest koncepcja przymierza - covenant.

Idea przymierza na Wyspach istotnego politycznego znaczenia nabrała po przekładzie Biblii Tyndale'a z 1532 roku, w którym hebrajski termin brit i grecki diatheke przetłumaczono $\mathrm{z}$ premedytacją jako covenant ${ }^{41}$. Przymierze $\mathrm{z}$ Bogiem stało się dla protestantów wygodnym, zainspirowanym Starym Testamentem ${ }^{42}$, narzędziem zakwestionowania politycznego, religijnego oraz społecznego status quo jako historycznej i etycznej podstawy każdego rządu i porządku prawnego. Na podatny grunt trafiła zwłaszcza w Szkocji, gdzie od dawna istniała tradycja kontraktów pomiędzy klanami i ich grupami. Związki, pakty i przysięgi zawierane były tu w celu wspólnej obrony i polubownego załatwiania sporów. Nietrudno było zatem tradycje te połączyć ze zreformowanym pojęciem przymierza, szczególnie w kontekście obrony ich wersji kalwinizmu. W konsekwencji w Szkocji powstał pomysł,

39 J. Knox, Summary of the second blast, [w:] idem, On Rebellion, Cambridge-New York-Melbourne 2004, s. 128-129.

40 B. Peardon, The politics of polemic: John Ponet's short treatise of politic power and contemporary circumstance, 1553-1556, „Journal of British Studies” 22, 1982, s. 46.

41 D.J. Elazar, Covenant and Commonwealth. From Christian Separation through the Protestant Reformation. The Covenant Tradition in Politics, t. 2, New Brunswick 1998, s. 231.

42 H. Silving, The jurisprudence of the Old Testament, „New York University Law Review” 28, 1953, s. 1130-1131.

Studia nad Autorytaryzmem i Totalitaryzmem 42, nr 1, 2020

(C) for this edition by CNS 
aby konstrukcję tę wykorzystać do uzasadnienia prawowitości i celów relacji publicznych $^{43}$, przede wszystkim właśnie za sprawą Knoxa, który rozwijał pomysły Zwingliego oraz Bullingera ${ }^{44}$ i nadał idei covenant politycznego wymiaru ${ }^{45}$.

Ideę Kalwina o przymierzu między Bogiem a człowiekiem ${ }^{46}$ Knox przeniósł na płaszczyznę publiczną, pisząc o przymierzu między Bogiem a wiernymi ${ }^{47}$. W ten sposób przymierze zawarte między Adamem i później Abrahamem a Bogiem stało się $\mathrm{w}$ kalwińskiej teologii rodzajem specjalnej konstytucji danej przez Stwórcę rodzajowi ludzkiemu, a przestrzeganie boskich praw było w niej gwarancją boskiego błogosławieństwa. W tym kontekście reformacja i odrzucenie rzymskiego Antychrysta przyniosły powrót do czystości religii i odnowienie przymierza między ludem Szkocji a Chrystusem ${ }^{48}$, czyniąc ze Szkotów naród wybrany i inkarnację Izraela ${ }^{49}$, a Kirk ,jednym z najczystszych dziś kościołów pod niebem, zarówno w szacunku dla prawdziwej doktryny, jak i czystości kultu" ${ }^{50}$. Knox - a później w ślad za nim jego radykalni uczniowie: Melville, Rutherford czy Gillespie - dowodził bowiem ciągłości przymierza między Szkocją a Izraelem, od Abrahama, przez Mojżesza i Dawida, aż po Chrystusa. Władcy tego królestwa są zatem zobowiązani rządzić nim zgodnie z wolą bożą i popierać prawdziwą wiarę ${ }^{51}$. Dlatego władza zarówno cywilna, jak i kościelna (choć od siebie oddzielone) muszą być posłuszne wobec Boga, który swa wolę ujawnił w Piśmie Świętym. Państwo Knoxa ma więc w konsekwencji charakter teonomiczny. Jak pisze:

Boska sprawiedliwość, będąc nieskończona i niezmienna, wymaga posłuszeństwa w sprawach religii od wszystkich, którzy są z nim sprzymierzeni [...], czego wymaga od każdego narodu (lub od każdego człowieka) we wszystkich poprzedzających nas czasach. Ponieważ wszyscy będący z nim w przymierzu są jednym ciałem, jak zaświadcza Mojżesz, zaliczając w to mężczyzn, kobiety, dzieci, sługi, książąt, duchownych, władców, urzędników i obcych będących w przymierzu Pana. Zatem to oczywiste, że dla jednego ciała musi być jedno prawo, by tego, czego Bóg wymaga od jednego, było wymaganym od wszystkich ${ }^{52}$.

43 D.J. Elazar, op. cit., s. 271.

44 A.W.G Raath, S.A. de Freitas, Calling and resistance: Huldrych Zwingli's (1484-1531) political theology and his legacy of resistance to tyranny, „Koers” 66, 2002, $\mathrm{nr} 1$, s. 71.

45 R.L. Greaves, John Knox and the covenant tradition, „Journal of Ecclesiastical History” 24, 1973, nr 1, s. 26-29.

46 Zob. B. Macedo, Covenant theology in the thought of John Calvin: From the covenant of works to the Abrahamic covenant, „Fides Reformata” 1, 2015, s. 89-105.

47 W.S. Reid, John Knox's theology..., s. 531.

48 Ch. Hill, The English Bible and the Seventeenth-Century Revolution, London 2014, s. 182.

49 S.A. Burrell, The covenant idea as a revolutionary symbol: Scotland, 1596-1637, „Church History" 27, 1958, s. 348.

50 The Booke of the Universall Kirk. Acts and Proceedings of the General Assemblies of the Kirk of Scotland, 1560-1618, t. 3, Edinburgh 1845, s. 1139.

51 W.S. Reid, John Knox. The first of the Monarchomachs?, [w:] The Covenant Connection. From Federal Theology to Modern Federalism, red. D.J. Elazar, J. Kincaid, Lanham 2000, s. 122.

52 J. Knox, A godly letter of warning..., s. 191.

Studia nad Autorytaryzmem i Totalitaryzmem 42, nr 1, 2020

(C) for this edition by CNS 
Odrzucenie bałwochwalstwa i przestrzeganie prawa bożego jest więc najważniejszym elementem kontraktu z Bogiem ${ }^{53}$. Dlatego rządy katolickich władców były dla niego złamaniem przymierza ${ }^{54}$, rządami bałwochwalców i tyranów, przed którymi wspólnotę może ochronić jedynie aktywne stawienie oporu ${ }^{55}$. Wedle Knoxa, aby utrzymać przymierze z Bogiem, władza cywilna — podobnie jak w Izraelu i Judzie - musi dbać o czystość religii ${ }^{56}$. Między innymi za jego sprawą w szkockim kalwinizmie, pod wpływem koncepcji hugenockich ${ }^{57}$, skrystalizował się więc pogląd, że przymierze religijne jest trójstronnym kontraktem pomiędzy królem, ludźmi a Bogiem ${ }^{58}$, mającym na celu strzec czystości prawdziwej zreformowanej religii i Kościoła. Działanie w jego ramach było w istocie kontraktem konstytucyjnym między królem z jednej a ludem z drugiej strony dla zachowania porządku, dobrego rządu i ochrony religii ${ }^{59}$. Jeśli zatem władca nie rządzi zgodnie z Pismem Świętym, przymierze zostaje złamane, a ludzie mogą usunąć $z$ tronu swego władcę ${ }^{60}$.

Co ważne, przymierze z Bogiem wiąże więc nie tylko króla, ale i cały lud boży. Dlatego to również na nim spoczywa obowiązek troski o czystość religii. Kogo jednak należy rozumieć pod pojęciem „lud”? Istotną wskazówkę w tej materii dostarcza list do szlachty datowany 27 grudnia 1557 roku, czyli zaraz po nieudanym powrocie Knoxa do kraju, gdy lordowie w ostatniej chwili odmówili mu swego poparcia ${ }^{61}$. Myśliciel wskazuje w nim, że to na barkach szlachty, ponieważ reprezentuje ona stany królestwa, spoczywa odpowiedzialność za losy państwa i jego wierność prawdziwej religii w sytuacji, gdy władca jest bałwochwalcą. Gani ją równocześnie, że zdradziła swych poddanych, dzieci i przyszłych potomków, pisząc, że

wasi poddani (będący waszymi braćmi) są uciskani, a ich ciała i dusze trzymane w niewoli. A Bóg przemawia do waszych sumień (chyba że umarliście razem z zaślepionym światem), że powinniście zaryzykować własnym życiem (czy to przeciw królom, czy cesarzom), aby

53 A.W.G Raath, S.A. de Freitas, op. cit., s. 7.

54 Q. Skinner, op. cit., s. 238.

55 R.A. Mason, Introduction, [w:] J. Knox, On Rebellion, Cambridge-New York-Melbourne 2004, s. xi-xii.

56 J. Knox, A brief exhortation..., s. 511; zob. też M.Ch. Bell, Calvin and Scottish Theology. The Doctrine of Assurance, Edinburgh 1985, s. 42.

57 J.L. O'Donovan, Political authority and European community: The challenge of the Christian political tradition, „Scottish Journal of Theology” 47, 1994, nr 1, s. 8-9.

58 R.L. Greaves, Concepts of political obedience in late Tudor England: Conflicting perspectives, „Journal of British Studies” 22, 1982, nr 1, s. 26.

59 A.I. Macinnes, The Scottish Constitution, 1638-51. The rise and fall of oligarchic centralism, [w:] The Scottish National Covenant in its British Context, red. J. Morrill, Edinburgh 1990, s. 110.

60 W.C. Dickinson, Introduction, [w:] J. Knox, History of the Reformation in Scotland, Edinburgh 1949, s. liii.

61 T. M'Crie, Life of John Knox, [w:] The Works of Thomas M'Crie, t. 1, Edinburgh-London 1885, s. 99-100.

Studia nad Autorytaryzmem i Totalitaryzmem 42, nr 1, 2020

(C) for this edition by CNS 
ich uwolnić. Albowiem tylko z tego powodu nazywacie się książętami ludu i otrzymujecie od swych braci cześć, uznanie i szacunek - nie z uwagi na wasze urodzenie i pochodzenie (jak większość ludzi fałszywie sądzi), lecz z powodu swego urzędu i obowiązku, którym jest obrona ze wszystkich sił waszych poddanych i braci od wszelkiej przemocy i ucisku ${ }^{62}$.

Widać zatem u Knoxa elementy teorii eforalnej63, którą w pełni wyłożył $\mathrm{w}$ The appellation to the nobility and estates. Podkreśli $\mathrm{w}$ nim, że by cieszyć się życiem wiecznym, należy odrzucić rzymskie bałwochwalstwo — Anglia i Szkocja zostały bowiem powołane, aby dochować przymierza z Bogiem, a posłuszeństwo jest warunkiem bożego miłosierdzia ${ }^{64}$. Knox wskazuje przy tym, że wszystkie urzędy publiczne mają również charakter boży, a ich władza wypływa z tego samego źródła co władza króla. Tak jak on mają więc obowiązek zreformować religię zgodnie z prawem bożym i pełnić funkcje przyznane przez Stwórcę władzy, niezależnie od postawy panującego. Takimi urzędnikami w Szkocji są dla Knoxa przedstawiciele szlachty, która ma „legalną władzę ustanowioną przez Boga"65. Im także Bóg powierzył prawo miecza, by „ochraniali niewinnych i karali złoczyńców" ${ }^{66}$. Na równi z księciem dzierżą więc miecz sprawiedliwości i muszą wykonywać swoje obowiązki, nawet gdy zaniedbuje je władza zwierzchnia. Książęta i urzędnicy państwowi są bowiem powołani nie po to, aby sprawować tyrańską władzę nad ludem, lecz na mocy przymierza są ustanowieni przez Boga, aby dbać o jego pomyślność i pożytek. Wobec tego obowiązkiem szlachty jako niższych urzędników jest przeciwstawienie się tyranii najwyższego urzędnika, gdy przekracza granice władzy danej mu od Boga. Gdy zatem władca sprzeniewierzy się tej funkcji, gdy zwalcza prawdziwą religię, działa przeciwko bożej chwale i swoim braciom, jego działania nie mają już boskiej sankcji, a poddani zwolnieni są z obowiązku posłuchu. Król staje się bowiem wtedy uzurpatorem, pozbawionym bożej legitymacji. Gdy tak się dzieje, niżsi urzędnicy powinni bronić bożego prawa, wykonując boży rozkaz, który nakazuje wypowiedzenie

62 J. Knox, To some of the nobility in Scotland, [w:] idem, On Rebellion..., s. 137.

63 Teoria eforalna pojawia się zatem u Knoxa, zanim została wyłożona przez Kalwina w wydaniu Institutio z 1559 roku. Funkcjonowała ona jednak znaczenie wcześniej wśród luteranów, co najmniej od Wyznania magdeburskiego z 1550 roku (zob. C.G. Bowman, The development of the Lutheran theory of resistance: 1523-1530, „Sixteenth Century Journal” 8, 1977, nr 1, s. 61-76). Pod ich wpływem przyjęta została także wśród kalwinów, najpierw przez Bézę w De haereticis a civili magistratus puniendis z 1554 roku, później zaś Poneta w A Short Treatise of Politike Power z 1556 roku oraz Goodmana w How Superior Powers Ought to be Obeyed of their Subjects z 1558 roku. Funkcjonowała więc wśród kalwinów i była znana zarówno Kalwinowi, jak i Knoxowi przebywającemu na emigracji.

64 R. Mason, Covenant and Commonweal: The language of politics in reformation Scotland, [w:] Church, Politics and Society. Scotland 1408-1929, red. N. MacDougall, Edinburgh 1983, s. 99.

$65 \mathrm{~J}$. Knox, The appellation from the sentence pronounced by the bishops and clergy: Addressed to the nobility and estates of Scotland, [w:] The Works of John Knox, t. 4, s. 482.

66 Ibidem.

Studia nad Autorytaryzmem i Totalitaryzmem 42, nr 1, 2020

(C) for this edition by CNS 
posłuszeństwa i nagradza przeciwstawienie się bezbożnemu tyranowi, a nawet jego zabicie ${ }^{67}$. Zwracając się do szlachty, Knox pisze:

I dlatego, moi Lordowie, zwróćcie uwagę, że Bóg uzbroił wasze ręce w miecz sprawiedliwości, widząc, że jego oczywisty rozkaz nakazuje bałwochwalcom i fałszywym prorokom śmierć i że jesteście ponad swymi poddanymi, by panować jako ojcowie nad swoimi dziećmi ${ }^{68}$.

\section{Dlatego}

ze względu na wasze urzędy jesteście zobowiązani nie tylko do tego, by powstrzymać tyranię, lecz także karać ich (tyranów) jak złodziei i morderców, jak bałwochwalców i bluźnierców wobec Boga ${ }^{69}$.

Podobnie zatem jak Kalwin nie przyznaje Knox (w ramach tej argumentacji) prawa do rebelii jednostkom ani zwykłemu ludowi, lecz jedynie szlachcie. Tyrania interpretowana jest przy tym przez tego myśliciela w kategoriach czysto religijnych. Niewiele interesuje go prawo pozytywne, jedynym probierzem legalności władzy jest wyznawanie i wspieranie prawdziwej religii, dlatego tam, gdzie pisze o tyranii, ma na myśli ,diabelskie bałwochwalstwo, papieskie obrzydliwości i jego [papieża - T.T.] uzurpatorską tyranię"70. Dlatego nikt, kto narzuca ludowi bałwochwalstwo, nie może być zwolniony z kary śmierci. Jego pozycja nie ma przy tym żadnego znaczenia — nieważne, czy jest to monarcha, czy szlachcic — ponieważ ukaranie takiej osoby jest obowiązkiem narzuconym na każdego członka wspólnoty zależnie od jego możliwości.

Teoria eforalna ma jednak u Knoxa subsydiarny charakter. Równocześnie z jej krystalizacją w jego poglądach rozwija się koncepcja o wiele bardziej radykalna. Upominając szlachtę (możnych), zwraca się bowiem jednocześnie do szkockiego ludu rozumianego tym razem o wiele szerzej. W 1558 roku w A letter to the commonalty of Scotland Knox pisze więc, że

jest nie mniej konieczne poddanym wierzyć w Chrystusa i wyznawać prawdziwą religię niż księciu i królowi. Dlatego twierdzę, że wobec zaniedbania tego obowiązku w oboczności Boga nie będzie was usprawiedliwiać twierdzenie, że nie byliście władcami i nie dotyczyła was troska o reformowanie religii ${ }^{71}$.

Skoro Bóg wymaga od władcy, aby go naśladował, tego samego żąda od jego poddanych. Wszystkich łączy bowiem równość w Chrystusie, niezależnie od stanu, zamożności czy pozycji społecznej. Wspólnota wiernych jest u niego tożsama z wspólnotą państwową i określona w kategoriach kontraktowych, co powoduje,

67 T. M'Crie, John Knox. Containing Illustrations of the History of the Reformation in Scotland, Edinburgh 1831, s. 123-124.

68 J. Knox, The appellation..., s. 515.

69 Ibidem, s. 485.

70 Ibidem, s. 507.

71 J. Knox, A letter to the commonalty of Scotland 1558, [w:] The Works of John Knox, t. 4, s. 532.

Studia nad Autorytaryzmem i Totalitaryzmem 42, nr 1, 2020

(C) for this edition by CNS 
iż cała przejmuje na siebie zobowiązanie zapewnienia pobożnych rządów i staje się wrogiem każdego, kto wzbudza boży gniew. Każdy członek wspólnoty został tym samym zobowiązany do oporu i obalenia bałwochwalców i tyrańskich władców. Jest to zatem nie tyle uprawnienie, ile święty obowiązek, który wierni przyjęli na siebie na mocy przymierza ${ }^{72}$. Spoczywa on już nie tylko na niższych urzędnikach, lecz na całym ludzie bożym. Nie każdy władca ma więc boską legitymację, boską mocą obdarzona jest wspólnota, która będąc zbrojnym ramieniem Pana, jest powołana do zapewnienia panowania na ziemi prawdziwej wiary. Knox idzie zatem dalej niż w teorii eforalnej, przekonując, że jeśli szlachta zaniedbuje ten obowiązek i sprzymierza się z bałwochwalcą i Antychrystem, to obowiązek sprzeciwienia się mu ciąży właśnie na tytułowej

szarej masie. Mówiąc bardziej klarownie — oświadcza Knox — jeśli wasi książęta i władcy są winni (razem z biskupami) całego bałwochwalstwa i całej niewinnej krwi, która jest przelana dla świadectwa prawdy Chrystusa [...], również wy jesteście [...] przestępcami winnymi tych samych zbrodni razem z waszymi książętami i władcami, ponieważ wspieracie i utwierdzacie swych książąt w ślepej wściekłości i nie dajecie żadnej deklaracji, że ich tyrania wywołuje wasz gniew ${ }^{73}$.

Jeśli więc władca uciska lud, w sferze religii służąc szatanowi, ten ma prawo stawić mu odpór, nawet siłą. Myśl tę Knox rozwinie później w 1564 roku podczas debaty z Maitlandem, wskazując na przymierze, jakie bezpośrednio łączy lud z Bogiem i które daje podstawę, by opierać się siłą władzy i zniszczyć wszelkie bałwochwalstwo $^{74}$. Podczas dyskusji z Marią Stuart przypomni natomiast, że jeśli władcy złamią przymierze z Bogiem, muszą zostać powstrzymani przez swych poddanych.

Pamiętać wszakże należy, że oporu nie uzasadniały niewielkie odstępstwa religijne, pojedyncze akty okrucieństwa czy nadużycia władzy. Nie mogły one niweczyć boskiego nakazu posłuszeństwa tam, gdzie były jakiekolwiek wątpliwości co do tyranicznego charakteru rządu. Lecz jeśli jednak nie budził on wątpliwości, wtedy jego postawa, a za nim szkockich następców, była zdecydowana i nieznosząca kompromisów, poddani mieli absolutne prawo podjąć nawet zbrojną obronę tam, gdzie deptano ich prawa i wolności (przede wszystkim religijne), a władza odwoływała się do terroru ${ }^{75}$. Choć Knox pisze o poddanych, ma na tu myśli nie tylko całą wspólnotę polityczną, lecz także jej poszczególnych członków (na co mogą wskazywać pewne elementy zawarte już w The first blast). I choć nie pisze o tym wprost, to uzasadnieniem tak radykalnego stanowiska może być funkcjonujące w myśli kalwińskiej i będące podstawą argumentacji monarchomachów rozróżnienie urzędu i osoby władcy zaczerpnięte z Listu do Rzymian św. Pawła.

72 W.S. Reid, John Knox. The first of the Monarchomachs?, s. 127.

73 J. Knox, A letter to the commonalty..., s. 535.

74 R.L. Greaves, John Knox, the reformed tradition..., s. 18.

75 D. Macleod, The influence of Calvinism on politics, ,Theology in Scotland” 16, 2009, nr 2, s. 10.

Studia nad Autorytaryzmem i Totalitaryzmem 42, nr 1, 2020

(C) for this edition by CNS 
Ponet wskazywał przy tym wprost, że sprzeniewierzenie się swej roli przez naruszenie prawa bożego czyni z władcy osobę prywatną, której sprzeciwić się mogą również jednostki (miał tu na myśli Marię Tudor, nie mając nic przeciwko jej zabójstwu ${ }^{76}$ ).

Koncepcja ta nawiązuje do średniowiecznej idei wojny prywatnej, którą mogą toczyć jednostki w imię sprawiedliwego powodu. U Knoxa konwertuje ona w obowiązek jednostek toczenia takiej wojny przeciwko tyranowi, nie tylko wiążący szlachtę, ale też poszczególnych ludzi ${ }^{77}$, dając im prawo samodzielnego określenia legalności porządku politycznego (a w ślad za nim i religijnego). W argumentacji Knoxa pojawia się zatem nowy element, który stanie się później podstawą rewolucyjnych teorii Covenanters $^{78}$. Choć bowiem myśliciel ten twierdzi, że władza pochodzi od Boga, to sugeruje, że to ludzie przez akt wyboru władcy (dorozumiany bądź bezpośredni - jak w Starym Testamencie) są Jego agentami, a zatem władza króla pochodzi bezpośrednio od Boga i bezpośrednio od ludzi. Wobec tego jej źródłem jest jakaś postać kompaktu, a władza musi mieć warunkowy charakter ze wszystkimi tego konsekwencjami.

\section{Rekapitulacja}

Ostatecznie więc, wychodząc od stanowiska nakazującego obowiązek posłuchu wobec monarchy i dopuszczającego jedynie bierny opór, Knox odchodzi od umiarkowanego stanowiska Kalwina i Bullingera. Jego argumentacja pod wpływem wydarzeń politycznych w Szkocji i Anglii oraz radykalnych koncepcji pisarzy kalwińskich zmierza do uzasadnienia powszechnej rewolucji, a nawet królobójstwa. Jego kontakty z francuskimi hugenotami Hotmanem, Languetem i du Plessis-Mornayem nie wykluczają, że jego przemyślenia miały wpływ na sformułowane przez nich koncepcje oporu, choć w porównaniu z nimi jego przemyślenia uderzają prostotą ${ }^{79}$.

Niewątpliwie miał jednak wielki wpływ na angielskich purytanów — podczas pobytu na kontynencie poznał bowiem takich prominentnych przedstawicieli wspólnot protestanckich jak biskup Coverdale, biskup Bale, John Fox czy William Whittingham. Tam też mógł zapoznać ich ze swymi teoriami, wpłynąć

76 R.L. Greaves, Concepts of political obedience..., s. 25.

77 M.J. Larson, John Knox, [w:] War and Religion. An Encyclopedia of Faith and Conflict, red. J.M. Shaw, T.J. Demy, t. 1, Santa Barbara-Denver 2017, s. 466.

78 Terminem tym zwykło się określać sygnatariuszy Narodowego Przymierza z 1638 roku, wymierzonego przeciwko próbom narzucenia Szkocji przez Karola I Modlitewnika; zob. J. Coffey, The Impact of apocalypticism during the Puritan Revolutions, „Perichoresis” 4, 2006, nr 2, s. 122.

79 O. von Gierke, The Development of Political Theory, przeł. B. Freyd, W.W. Norton, New York 1939, s. 24.

Studia nad Autorytaryzmem i Totalitaryzmem 42, nr 1, 2020

(C) for this edition by CNS 
na ich poglądy i zaszczepić swoje w życie angielskiego Kościoła ${ }^{80}$. To między innymi jemu angielski purytanizm zawdzięcza tak radykalną zmianę ideologicznego profilu, choć radykalizm ten za czasów Elżbiety I był skutecznie i bezlitośnie pacyfikowany. Zatem także za jego sprawą jedno pokolenie dzieli umiarkowane Obedience of a Christian Man Tyndale'a, od rew olucyjnych traktatów Poneta i Goodmana, o których Anglicy przypomnieli sobie po śmierci Elżbiety. To właśnie jego „bezecnym inwektywom i nikczemnym paszkwilom” "81, jak określił je Jakub I (VI) Stuart, angielski purytanizm zawdzięcza swe oblicze. Oblicze, które w pełni ujawniło się podczas rządów jego syna. To Knox jest w dużym stopniu odpowiedzialny za postawę szkockich prezbiterian podczas rewolty purytańskiej, a najważniejszy szkocki traktat polityczny tego okresu - Lex, Rex Samuela Rutherforda — „wymyślony przeciwko monarchii i kładący grunt pod rebelię" 82 całymi garściami czerpie z pism Knoxa. Z tego samego powodu John Milton cytował jego pisma, oprócz dzieł Goodmana i Whittinghama, broniąc rewolucji i usprawiedliwiając egzekucję Karola I ${ }^{83}$.

\section{Bibliografia}

Augustyn z Hippony, Państwo Boże, przeł. W. Kubicki, Kęty 2002.

Bell M.Ch., Calvin and Scottish Theology. The Doctrine of Assurance, Edinburgh 1985.

The Booke of the Universall Kirk. Acts and Proceedings of the General Assemblies of the Kirk of Scotland, 1560-1618, Edinburgh 1845.

Burrell S.A., The covenant idea as a revolutionary symbol: Scotland, 1596-1637, „Church History” 27, 1958, s. 330-350.

Calvin J., Commentaries on the Book of the Daniel, Edinburgh 1852.

Calvin J., Commentaries on the Epistle of Paul the Apostle to the Romans, Edinburgh 1849.

Calvin J., Institutes of the Christian Religion, Louisville 1960.

Camion C., The right of resistance in Jean Calvin and the Monarchomachs, „La revue de philosophie de l'Université de Montréal" 2009, nr 5, s. 1-25.

Church, Politics and Society. Scotland 1408-1929, red. N. MacDougall, Edinburgh 1983.

Coffey J., The impact of apocalypticism during the Puritan Revolutions, „Perichoresis” 4, 2006, nr 2, s. 117-147.

The Covenant Connection. From Federal Theology to Modern Federalism, red. D.J. Elazar, J. Kincaid, Lanham 2000.

80 P. Lorimer, John Knox and the Church of England: His Work in Her Pulpit and His Influence Upon Her Liturgy Articles and Parties, Whitefish 2004, s. 2.

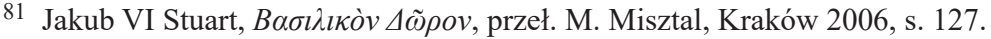

82 Sketch of the Life of Samuel Rutherford, [w:] S. Rutherford, Lex, Rex, or The Law and the Prince; A dispute for The Just Prerogative of King and People: containing The reasons and causes of the most necessary defensive wars of the Kingdom of Scotland, and of their Expedition for the aid and help of their dear brethren of England; in which their innocency is asserted, and a full answer is given to a seditious pamphlet, entitled, Sacro-Sancta Regnum Majestatis, Edinburgh 1843, s. xxi.

83 J. Milton, The tenure of kings and magistrates, [w:] The Prose Works of John Milton, t. 2, London 1848, s. 39-40.

Studia nad Autorytaryzmem i Totalitaryzmem 42, nr 1, 2020

(C) for this edition by CNS 
Elazar D.J., Covenant and Commonwealth. From Christian Separation through the Protestant Reformation. The Covenant Tradition in Politics, t. 2, New Brunswick 1998.

Fisher G.P., The Reformation, New York 1873.

Gierke O. von, The Development of Political Theory, przeł. B. Freyd, W.W. Norton, New York 1939.

Grant Bowman C., The development of the Lutheran theory of resistance: 1523-1530, „Sixteenth Century Journal" 8, 1977, nr 1, s. 61-76.

Greaves R.L., Concepts of political obedience in late Tudor England: Conflicting perspectives, „Journal of British Studies” 22, 1982, nr 1, s. 23-34.

Greaves R.L., John Knox and the covenant tradition, „Journal of Ecclesiastical History” 24, 1973, nr 1, s. 23-32.

Greaves R.L., John Knox, the reformed tradition, and the development of resistance theory, „The Journal of Modern History" 48, 1976, nr 3. On Demand Supplement, s. 1-36.

Hill Ch., The English Bible and the Seventeenth-Century Revolution, London 2014.

Höpfl H., The Christian Polity of John Calvin, London-New York-New Rochelle-Melbourne-Sidney 1982.

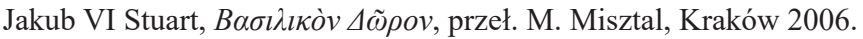

John Knox and the Church of England, London 1875.

Knox J., History of the Reformation in Scotland, Edinburgh 1949.

Knox J., On Rebellion, Cambridge-New York-Melbourne-Madrid-Cape Town 2004.

Lang A., Knox and the Reformation, Whitefish 2004.

Letters of John Calvin, Philadelphia 1858.

Lorimer P., John Knox and the Church of England: His Work in Her Pulpit and His Influence Upon Her Liturgy Articles and Parties, Whitefish 2004.

M'Crie T., John Knox. Containing Illustrations of the History of the Reformation in Scotland, Edinburgh 1831.

Macedo B., Covenant theology in the thought of John Calvin: From the covenant of works to the Abrahamic covenant, „Fides Reformata” 1, 2015, s. 89-105.

MacGregor G., The Thundering Scot, Philadelphia 1957.

Macleod D., The influence of Calvinism on politics, „Theology in Scotland” 16, 2009, nr 2, s. 5-26.

McNeill J.T., The History and Character of Calvinism, New York 1954.

Nijenhuis W., Ecclesia Reformata. Studies on the Reformation, Leiden-New York-Köln 1994.

O'Donovan J.L., Political authority and European community: The challenge of the Christian political tradition, „Scottish Journal of Theology” 47, 1994, nr 1, s. 1-18.

Peardon B., The politics of polemic: John Ponet's short treatise of politic power and contemporary circumstance, 1553-1556, „Journal of British Studies” 22, 1982, s. 35-49.

The Prose Works of John Milton, London 1848.

Raath A.W.G., Freitas S.A. de, Calling and resistance: Huldrych Zwingli's (1484-1531) political theology and his legacy of resistance to tyranny, „Koers” 66, 2002, nr 1, s. 45-76.

Readings in Calvin's Theology, red. D. McKim, Grand Rapids 1984.

Reeves R.M., English Evangelicals and Tudor Obedience, c. 1527-1570, Leiden-Boston 2014.

Reid W.S., John Knox's theology of political government, „Sixteenth Century Journal” 19, 1988, nr 4, s. 529-540.

Reid W.S., Trumpeter of God, New York 1974.

Rutherford S., Lex, Rex, or The Law and the Prince; A dispute for The Just Prerogative of King and People: containing The reasons and causes of the most necessary defensive wars of the Kingdom of Scotland, and of their Expedition for the aid and help of their dear brethren of England; in which their innocency is asserted, and a full answer is given to a seditious pamphlet, entitled, Sacro-Sancta Regnum Majestatis, Edinburgh 1843.

The Scottish National Covenant in its British Context, red. J. Morrill, Edinburgh 1990.

Studia nad Autorytaryzmem i Totalitaryzmem 42, nr 1, 2020

(C) for this edition by CNS 
Silving H., The jurisprudence of the Old Testament, „New York University Law Review” 28, 1953, s. $1129-1148$.

Skinner Q., The Foundations of Modern Political Thought, t. 2. The Age of Reformation, New York 1978.

Szczech T., Państwo i prawo w doktrynie św. Augustyna, Marcina Lutra i Jana Kalwina, Łódź 2006.

Szlachta B., Konstytucjonalizm czy absolutyzm? Szkice z francuskiej myśli politycznej XVI wieku, Kraków 2005.

War and Religion. An Encyclopedia of Faith and Conflict, red. J.M. Shaw, T.J. Demy, Santa Barbara-Denver 2017.

The Works of John Knox, Edinburgh 1895.

Works of Thomas M'Crie, Edinburgh-London 1885. 